\title{
PERAN WAKAF DALAM MENINGKATKAN PEMBERDAYAAN EKONOMI UMAT
}

\author{
Septi Purwaningsih ${ }^{1 *}$ dan Dewi Susilowati ${ }^{1}$ \\ ${ }^{1}$ Program Pascasarjana Magister Akuntansi, Fakultas Ekonomi dan Bisnis, Universitas Jenderal \\ Soedirman, Indonesia \\ *Email corresponding: septi.purwaningsih@gmail.com
}

\begin{abstract}
Abstrak
Indonesia merupakan Negara yang mayoritas penduduknya beragama Islam. Tidak hanya aspek ibadah yang diatur dalam Islam namun mencakup muamalah juga didalamnya yang bertujuan untuk kesejahteraan bersama. Salah satu ibadah yang berdampak pada kesejahteraan umat adalah wakaf. Masyarakat Indonesia masih sangat awam dengan wakaf produktif yang sangat berguna bagi pengentasan kemiskinan di Indonesia. Beragamnya wakaf produktif dan dengan kesadaran masyarakat muslim di Indonesia diharapkan wakaf dapat berkembang sehingga dapat memberdayakan mayarakat yang membutuhkan. Penelitian ini bertujuan untuk mengetahui peran wakaf dalam meningkatkan ekonomi umat di Indonesia. Metodologi penelitian yang digunakan adalah literature review. Sumber rujukan dari penelitian ini adalah penelitian terdahulu mengenai wakaf produktif.
\end{abstract}

Kata Kunci : Wakaf, Wakaf produktif, Ekonomi, Kemiskinan

\begin{abstract}
Indonesia is a country with a Muslim majority population. Islam does not only regulate the worship affairs but also regulate in muamalah which aims for mutual prosperity. One of the worship services that affect the welfare of the people is waqf. Indonesian society is still very common with productive waqf which is very useful for poverty alleviation in Indonesia. Diversity of productive waqf and with Muslim communities awareness in Indonesia is expected waqf can develop to empower the people in need. The purpose of this study was to determine the role of waqf in improving the economic community in Indonesia. The research methodology used was literature review. The reference source of this research was previous research concerning productive waqf.
\end{abstract}

Keywords: Waqf, Productive Waqf, Economy, Poverty.

\section{PENDAHULUAN}

Islam adalah agama yang sempurna yang berarti lengkap menyeluruh, dan mencakup panduan segala aspek kehidupan yang dibutuhkan oleh manusia. Aspek tersebut tidak hanya mencakup ibadah saja namun mencakup muamalah juga didalamnya yang bertujuan untuk kesejahteraan bersama. Dalam Islam ada beberapa aktifitas ibadah yang berdampak pada kesejahteraan umat, salah satunya adalah wakaf.

Wakaf merupakan salah satu cara penggunaan harta yang dianjurkan oleh Allah SWT dan Rosulullah SAW. Fungsi wakaf menurut Undang-Undang Nomor 41 Tahun 2004 pasal 5 adalah mewujudkan potensi dan manfaat ekonomis harta benda wakaf untuk kepentingan 
ibadah dan untuk memajukan kesejahteraan umum. Fungsi wakaf itu terbagi menjadi empat fungsi, yaitu yang pertama adalah fungsi ekonomi merupakan sebagai suatu sistem transfer kekayaan yang efektif. Kedua fungsi sosial yang jika dilaksanakan dengan baik, berbagai kekurangan akan fasilitas dalam masyarakat akan lebih mudah teratasi. Ketiga fungsi ibadah sebagai bentuk ibadah dalam pelaksanaan perintah Allah SWT, serta dalam memperkokoh hubungan dengan-Nya. Serta yang keempat adalah fungsi akhlaq dimana wakaf akan menumbuhkan akhlaq yang baik dimana setiap orang rela mengorbankan apa yang paling dicintainya untuk suatu tujuan yang lebih tinggi dari pada kepentingan pribadinya

Wakaf di Indonesia sangat potensial karena Indonesia merupakan negara yang mayoritas penduduknya adalah muslim dan sebagai pemeluk Islam terbesar di dunia. Kesadaran pemeluk agama Islam mengenai bagaimana pentingnya wakaf sangat penting. Karena tanpa adanya kesadaran itu maka potensi wakaf tidak akan dapat tergali. Selain itu juga pengelolaan yang baik juga sangat dibutuhkan

Kepala Divisi Pengelolaan \& Pemberdayaan Badan Wakaf Indonesia (Intan, 2017), mengungkapkan bahwa potensi wakaf bisa menjadi instrumen pembiayaan alternatif yang dapat menunjang pertumbuhan ekonomi masyarakat di Indonesia. Potensi wakaf di Indonesia bisa mencapai Rp 180 triliun, sedangkan total dana wakaf yang sudah tehimpun sampai dengan bulan Desember 2017 yaitu sebesar Rp 400 miliar. Potensi wakaf yang begitu besar hendaknya dapat dimanfaatkan bagi kesejahteraan umat dengan sebaik baiknya, apalagi melihat kondisi perekonomian rakyat Indonesia yang jumlah penduduknya mencapai 265 juta jiwa pada tahun 2018 dan jumlah penduduk miskinnya mencapai 25,67 juta, yang berarti 9,66 \% rakyat Indonesia mengalami kemiskinan (data BPS, 2018).

Wakaf biasanya sangat identik dengan wakaf berupa benda tak bergerak dan dimanfaatkan tidak secara produktif. Data dari Badan Wakaf Indonesia pada tahun 2016 menunjukkan nominal aset wakaf nasional sebesar 4,359 miliar meter persegi tanah yang berada di 435.768 titik di Indonesia. Jika diasumsikan harga tanah Rp100.000 per meter persegi maka nominal aset wakaf tersebut menjadi Rp435 triliun. Dibawah ini merupakan tabel aset wakaf yang berupa tanah di Indonesia.

Tabel 1. Data Tanah Wakaf Seluruh Indonesia

\begin{tabular}{rlrrrr}
\hline No & \multicolumn{1}{c}{ Propinsi } & Jumlah & \multicolumn{1}{c}{$\begin{array}{c}\text { Ada } \\
\text { Sertifikat }\end{array}$} & $\begin{array}{c}\text { Belum Ada } \\
\text { Sertifikat }\end{array}$ & \multicolumn{1}{c}{ Total Luas (M2) } \\
\hline $\mathbf{1}$ & $\begin{array}{l}\text { Nanggroe Aceh } \\
\text { Darussalam }\end{array}$ & 24.898 & 13.730 & 11.168 & $767.869 .011,58$ \\
\hline $\mathbf{2}$ & Sumatera Utara & 16.280 & 7.761 & 8.519 & $36.035 .460,00$ \\
\hline $\mathbf{3}$ & Sumatera Barat & 6.643 & 4.420 & 2.223 & $212.212 .380,00$ \\
\hline $\mathbf{4}$ & Sumatera Selatan & 6.394 & 3.521 & 2.873 & $380.456 .227,29$ \\
\hline $\mathbf{5}$ & Riau & 8.152 & 2.641 & 5.691 & $1.183 .976 .528,00$ \\
\hline $\mathbf{6}$ & Jambi & 5.918 & 3.785 & 2.133 & $13.516 .703,00$ \\
\hline $\mathbf{7}$ & Bengkulu & 2.759 & 1.869 & 890 & $7.122 .171,22$ \\
\hline $\mathbf{8}$ & Lampung & 14.591 & 8.372 & 6.219 & $22.990 .814,00$ \\
\hline $\mathbf{9}$ & Bangka Belitung & 1.133 & 779 & 354 & $3.243 .060,00$ \\
\hline $\mathbf{1 0}$ & Kepulauan Riau & 1.187 & 326 & 861 & $1.066 .799,00$ \\
\hline $\mathbf{1 1}$ & DKI Jakarta & 7.422 & 4.623 & 2.799 & $3.013 .640,00$ \\
\hline $\mathbf{1 2}$ & D.I. Yogyakarta & 8.547 & 8.051 & 496 & $2.933 .943,00$ \\
\hline $\mathbf{1 3}$ & Jawa Barat & 74.860 & 45.873 & 28.987 & $116.662 .017,81$ \\
\hline & & & & & \\
\hline
\end{tabular}




\begin{tabular}{|c|c|c|c|c|c|}
\hline 14 & Jawa Tengah & 103.294 & 82.641 & 20.653 & $163.169 .706,97$ \\
\hline 15 & Jawa Timur & 74.429 & 54.193 & 20.236 & $58.239 .272,20$ \\
\hline 16 & Banten & 20.089 & 11.049 & 9.040 & $39.322 .270,00$ \\
\hline 17 & Bali & 1.399 & 1.132 & 267 & $13.990 .000,00$ \\
\hline 18 & Kalimantan Barat & 4.467 & 2.257 & 2.210 & $27.544 .360,00$ \\
\hline 19 & $\begin{array}{l}\text { Kalimantan } \\
\text { Tengah }\end{array}$ & 2.642 & 1.631 & 1.011 & $5.778 .500,00$ \\
\hline 20 & $\begin{array}{l}\text { Kalimantan } \\
\text { Selatan }\end{array}$ & 9.265 & 7.582 & 1.683 & $58.239 .272,20$ \\
\hline 21 & $\begin{array}{l}\text { Kalimantan } \\
\text { Timur }\end{array}$ & 3.423 & 772 & 2.651 & $13.984 .104,00$ \\
\hline 22 & Sulawesi Utara & 887 & 420 & 467 & $1.905 .272,70$ \\
\hline 23 & $\begin{array}{l}\text { Sulawesi } \\
\text { Tenggara }\end{array}$ & 2.386 & 1.516 & 870 & $5.225 .958,00$ \\
\hline 24 & Sulawesi Tengah & 3.173 & 2.051 & 1.122 & $165.042 .816,23$ \\
\hline 25 & Sulawesi Selatan & 10.440 & 5.486 & 4.954 & $1.029 .030 .278,00$ \\
\hline 26 & Sulawesi Barat & 2.448 & 571 & 1.877 & $3.251 .700,00$ \\
\hline 27 & Papua & 346 & 142 & 204 & $694.466,00$ \\
\hline 28 & Papua Barat & 338 & 105 & 233 & $591.117,00$ \\
\hline 29 & $\begin{array}{l}\text { Nusa Tenggara } \\
\text { Timur }\end{array}$ & 1.272 & 1.047 & 225 & $5.311 .787,00$ \\
\hline 30 & $\begin{array}{l}\text { Nusa Tenggara } \\
\text { Barat }\end{array}$ & 12.105 & 7.031 & 5.074 & $25.816 .325,00$ \\
\hline 31 & Maluku & 1.215 & 449 & 766 & $5.006 .359,00$ \\
\hline 32 & Maluku Utara & 1.489 & 605 & 543 & $30.223 .191,00$ \\
\hline 33 & Gorontalo & 1.877 & 729 & 1.148 & $1.663 .350,00$ \\
\hline & JUMLAH & 435.768 & 287.160 & 148.447 & $4.359 .443 .170,00$ \\
\hline
\end{tabular}

Sumber : Direktorat Pemberdayaan Wakaf Kementerian Agama RI bulan Maret 2016

Badan Wakaf Indonesia mencatat dari 420 ribu hectare luas tanah wakaf di Indonesia namun baru $62 \%$ yang memiliki sertifikat wakaf, sehingga masih banyak tanah yang terbengkalai (Prymadhita, 2017). Tanah wakaf yang tidak memiliki sertifikat rawan akan terjadinya konflik. Misalnya saja tanah yang diwakafkan sudah dibangun tempat ibadah atau fasilitas umum lainnya namun ketika harga tanah daerah tersebut naik maka keluarga sang pemilik tanah meminta tanah ini kembali padahal sudah diwakafkan. Konflik kerap kali terjadi jika tidak memiliki sertifikat tanah yang jelas.

Pengelolaan dan pengembangan wakaf merupakan tanggung jawab bersama bagi pemerintah, ulama dan juga masyarakat (Hazami, 2016). Masalah tidak maksimalnya wakaf disebabkan oleh 3 elemen, yaitu peran pemerintah yang hendaknya lebih peduli terhadap pengoptimalan wakaf misalnya saja dengan membuat aturan yang lebih jelas tentang pengelolaan serta pengembangan wakaf dan juga dengan memaksimalkan kerja Badan Wakaf Indonesia untuk mengawasi pengelola wakaf yang kurang amanah sehingga tidak ada harta wakaf yang terbengkalai sia-sia. Peran ulama juga sangat penting yaitu dengan memberikan ilmu kepada masyarakat tentang berbagai macam harta yang dapat diwakafkan dan penggunaan harta tersebut dengan dalil yang diperbolehkan sesuai dengan syariat sehingga masyarakat 
memiliki pandangan yang lebih luas. Masyarakat hendaknya memiliki kesadaran lebih agar mau mewakafkan hartanya agar dapat dimanfaatkan oleh orang banyak, sehingga berdampak luas manfaatnya.

Pemerintah Indonesia mulai memperhatikan potensi wakaf dan macam-macam wakaf sesuai dengan perkembangan zaman dengan diterbitkannya undang-undang tentang wakaf yaitu Undang-Undang No. 41 tahun 2004 tentang Wakaf dan PP No. 42 tahun 2006 tentang pelaksanaannya. Wakaf produktif akan sangat bermanfaat bagi kemajuan perekonomian di Indonesia. Pengelolaan dan pengembangan harta benda wakaf dilakukan secara produktif antara lain dengan cara pengumpulan, investasi, penanaman modal, produksi, kemitraan, perdagangan, agrobisnis, pertambangan, perindustrian, pengembangan teknologi, pembangunan gedung, apartemen, rumah susun, pasar swalayan, pertokoan, perkantoran, sarana pendidikan ataupun sarana kesehatan, dan usahausaha yang tidak bertentangan dengan syariah.

\section{METODE PENELITIAN}

Metodologi penelitian yang digunakan oleh penulis pada artikel ini adalah literature review mengenai peran wakaf produktif bagi peningkatan perekonomian umat. Sumber rujukan dari penelitian ini adalah penelitian terdahulu mengenai wakaf produktif. Literature review merupakan metode penelitian yang mengkaji secara kritis tentang pengetahuan, gagasan atau temuan yang terdapat pada tubuh literatur serta memberikan saran dan penyelesaian atas problem yang ada.

\section{PEMBAHASAN}

\section{Pengetian Wakaf}

Kata "wakaf" atau "waqf" berasal dari bahasa Arab "waqafa" yang berarti "menahan" atau "berhenti". Al Waqf dalam bahasa Arab mengandung beberapa pengertian yaitu menahan harta untuk di wakafan. Secara syariah wakaf berarti menahan harta dan memberikan manfaatnya di jalan Allah SWT (Sabiq, 2008).

Nurhayati (2015) menjelaskan bahwa pengertian istilah wakaf memiliki perbedaan di kalangan ahli fikih sehingga berbeda pula cara memandang hakikat wakaf. Perbedaan pandangan tentang terminologi wakaf menurut Madzhab Hanafi adalah menahan suatu benda yang menurut hukum, tetap milik si wakif/pewakaf dan mempergunakan manfaatnya untuk kebajikan. Hak kepemilikan tetap pada pewakaf, maka atas harta yang diwakafkan dapat ditarik kembali, dijual dan jika si pewakaf wafat maka harta itu menjadi harta warisan bagi ahli warisnya. Dengan demikian yang timbul dari wakaf hanyalah menyumbangkan manfaat sementara kepemilikan tetap milik wakif. Wakaf menurut madzhab Maliki adalah menahan benda milik pewakaf (dari penggunaan secara kepemilikan termasuk upah) tetapi membolehkan pemanfaatan hasilnya untuk tujuan kebaikan, yaitu pemberian manfaat benda secara wajar untuk suatu masa tertentu sesuai dengan akad wakaf dan tidak dibolehkan sebagi wakaf lafa (selamanya).

Madzhab Syafi'I dan Ahmad bin Hambali berpendapat bahwa wakaf adalah menahan harta pewakaf untuk bisa dimanfaatkan di segala bidang kemaslahatan dengan tetap melanggengkan harta tersebut sebagai taqarub (mendekatkan diri) kepada Allah SWT. Pewakaf tidak dapat melarang penyaluran harta tersebut, jika terdapat pelarangan maka hukum berhak memaksanya. Madzhab syafi'I mendefinisikan wakaf dengan tidak melakukan tindakan atas suatu benda yang statusnya dimiliki oleh Allah SWT dengan menyedekahkan manfaatnya untuk 
kepentingan sosial. Pendapat lainnya memiliki pengertian yang sama dengan pendapat ke tiga namun memiliki perbedaan pada kepemilikan atas benda yang diwakafkan yaitu menjadi pemilik penerima wakaf, meskipun ia tidak berhak melakukan suatu tindakan atas harta wakaf tersebut, baik menjualnya ataupun menghibahkannya.

Sabiq (2008) berpendapat bahwa pendapat yang paling kuat adalah pendapat dari madzhab Imam Syafi'i yaitu kepemilikan akan berpindah kepada Allah SWT bukan kepada pewakaf maupun penerima wakaf, sehingga wakaf tidak dapat dijual maupun dihibahkan. Pengertian wakaf menurut UU no. 41 tahun 2004 yaitu wakaf merupakan perbuatan hukum wakif (pihak yang mewakafkan) untuk memisahkan dan/atau menyerahkan sebagian harta benda miliknya untuk dimanfaatkan selamanya atau untuk jangka waktu tertentu sesuai dengan kepentingannya guna keperluan ibadah dan/atau kesejahteraan umum menurut syariah.

Dari uraian tersebut sekilas dapat kita nilai bahwa wakaf sama saja dengan ibadah yang menggunakan asas filantropi lainnya, yaitu hibah, infaq dan sedekah. Tapi jika dilihat secara detail maka akan terlihat perbedaan wakaf dengan yang lainnya.

Tabel 2. Perbedaan Wakaf dan Infaq/Shadaqoh/Hibah

\begin{tabular}{llll}
\hline \multicolumn{1}{c}{ Wakaf } & \multicolumn{3}{c}{ Infaq / Shadaqoh / Hibah } \\
\hline $\begin{array}{l}\text { Menyerahkan kepemilikan suatu barang pada } \\
\text { orang lain }\end{array}$ & $\begin{array}{l}\text { Menyerahkan kepemilikan suatu } \\
\text { kepada pihak lain }\end{array}$ & \\
\hline $\begin{array}{l}\text { Hak milik atas barang dikembalikan oleh Allah } \\
\text { Subhanahuwata'ala }\end{array}$ & $\begin{array}{l}\text { Hak milik atas barang diberi } \\
\text { penrimashodaqoh/ hibah }\end{array}$ & kepada \\
\hline $\begin{array}{l}\text { Objek wakaf tidak boleh diserahkan atau dijual } \\
\text { kepada pihak lain }\end{array}$ & $\begin{array}{l}\text { Objek shodaqoh / hibah dapat diberikan atau } \\
\text { dijual kepada pihak lain }\end{array}$ \\
\hline Manfaat barang biasanya dinikmati untuk & $\begin{array}{l}\text { Manfaat barang hanya dinikmati oleh } \\
\text { penerima shodaqoh / hibah }\end{array}$ \\
\hline Objek wakaf biasanya kekal zatnya & $\begin{array}{l}\text { Objek shodaqoh / hibah biasanya tidak kekal } \\
\text { zatnya }\end{array}$ \\
\hline $\begin{array}{l}\text { Pengelolaan objek wakaf biasanya diserahkan } \\
\text { kepada administatur yang biasa disebut nadzir }\end{array}$ & $\begin{array}{l}\text { Pengelolaan objek shodaqoh / hibah biasanya } \\
\text { diserahkan kepada si penerima }\end{array}$ \\
\hline
\end{tabular}

Sumber :Nurhayati, 2015

\section{Pengertian Wakaf Produktif}

UU no 41 tahun 2004 menjelaskan mengenai pengertian wakaf yaitu menyerahkan/ memisahkan harta benda yang dimanfaatkan untuk selamanya ataupun dalam jangka waktu tertentu untuk kepentingan ibadah maupun kesejahteraan umat menurut syariah. Berdasarkan undang-undang tersebut diperbolehkan tanah wakaf digunakan untuk kesejahteraan umat asal sesuai dengan syariah sehingga munculah wakaf produktif. Selain itu alasan lain munculnya wakaf produktif karena ketidakpuasan pemerintah terhadap pengelolaan wakaf sehingga memunculkan pardigma wakaf produktif (Mubarok, 2008).

\section{Landasan Hukum Wakaf Produktif}

Landasan hukum wakaf berbeda dengan zakat yaitu tidak secara eksplisit dijelaskan di dalam Al-Qur'an namun tetap merujuk kepada Al-Qur'an.

"Kamu sekali-kali tidak sampai kepada kebajikan (yang sempurna), sebelum kamu menafkahkan sehahagian harta yang kamu cintai.dan apa saja yang kamu nafkahkan Maka Sesungguhnya Allah mengetahuinya."(QS Ali Imran ayat 92)

Ayat ini mendorong manusia untuk berinfak dan berbagi. Bagi yang mempunyai kelebihan harta agar tidak merasa berat membantu, karena apa yang diwakafkan akan tumbuh 
berkembang dengan berlipat ganda (Rizqiyani, 2016). Berikut ini beberapa hadits yang menjadi dalil tentang wakaf pada umunya dan wakaf produktif pada khusunya :

Dari Ibnu 'Umar radhiyallahu 'anhuma, berkata bahwa "Umar pernah mendapatkan sebidang tanah di Khaibar lalu ia mengahadapRosulullah Shalallohu 'alaihi Wasallam meminta petunjuk tentang pengelolaannya seraya berkata "Wahai Rosulullah saya mendapatkan tanah di Khaibar dan menurut saya, saya belum pernah memiliki tanah yang lebih baik dari tanah tersebut". Beliau bersabda

"Kalau engkau mau, tahan pohonnya lalu sedekahkan buahnya."

Perawi hadits berkata, "Lalu Umar mewakafkan tanahnya dengan syarat pohonnya tidak boleh dijual, tidak boleh dihadiahkan, dan tidak boleh diwarisi.Hasil dari pohon tersebut disedekahkan kepada kaum fakir, kerabat-kerabat, budak-budak, orang-orang yang membela agama Allah, tamu, dan musafir yang kehabisan bekal.Namun tidak masalah bagi pengurus wakaf untuk memakan hasilnya dengan baik dan memberi makan teman-temannya yang tidak memiliki harta."(Muttafaq 'alaih. HR. Bukhari, no. 2772; Muslim, no. 1632).

\section{Syarat dan Rukun Wakaf}

Wakaf dinyatakan sah apabila telah terpenuhi rukun dan syaratnya. Menurut jumhur ulama dari mazhab Syafi'i, Maliki dan Hanbali, mereka sepakat bahwa rukun wakaf ada empat yaitu Wakif (orang yang berwakaf), Mauquf 'alaih (orang yang menerima wakaf), Mauquf (harta yang diwakafkan), dan Sighat (pernyataan wakif sebagai suatu kehendak untuk mewakafkan harta bendanya). Merujuk pada sebuah badan zakat yaitu dompet dhuafa menjelaskan tentang syarat pada setiap rukun-rukun tersebut, yang pertama yaitu Wakif adalah orang yang mewakafkan denmgan syarat cakap bertindak dalam membelanjakan hartanya. Kecakapan bertindak disini meliputi 4 macam kriteria, yaitu : Merdeka, Berakal sehat, Dewasa, Tidak di bawah pengampuan. Rukun yang kedua adalah Mauquf yang diartikan sebagai benda-benda yang diwakafkan yang dipandang sah apabila memenuhi syarat-syarat benda tersebut harus mempunyai nilai, benda bergerak atau benda tetap yang dibenarkan untuk diwakafkan, benda yang diwakafkan harus tertentu (diketahui) ketika terjadi wakaf, benda tersebut telah menjadi milik si wakif.

Rukun yang ketiga adalah Mauquf 'Alaih yaitu orang atau badan hukum yang berhak menerima harta wakaf dengan syarat harus dinyatakan secara tegas pada waktu mengikrarkan wakaf, kepada siapa/apa ditujukan wakaf tersebut, tujuan wakaf itu harus untuk ibadah. Rukun yang keempat adalah Shighat yaitu segala ucapan, tulisan atau isyarat dari orang yang berakad untuk menyatakan kehendak dan menjelaskan apa yang diinginkannya. Adapun syarat sahnya shighat adalah : Shighat harus munjazah (terjadi seketika), Shighat tidak diikuti syarat bathil. Shigaht tidak diikuti pembatasan waktu tertentu, Tidak mengandung suatu pengertian untuk mencabut kembali wakaf yang sudah dilakukan

\section{Macam-Macam Wakaf Produktif}

Semenjak kemunculan undang-undang tentang wakaf maka bermunculan pula persepsi jenis jenis wakaf di Indonesia, salah satunya adalah wakaf produktif. Wakaf produktif yang sesuai dengan pengertiannya adalah mengelola harta wakaf agar dapat menghasilkan barang dan jasa yang dapat dioperasikan sehingga dapat menghasilkan keuntungan finansial yang bisa disalurkan kepada yang berhak menerimanya. Kesimpulan dari pengertian tersebut adalah bahwa tidak ada batasan apapun tentang pengelolaan wakaf produktif ini, sehingga pengelolaan 
bisa dilakukan diberbagai bidang selama bidang tersebut tidak melanggar aturan syariat. Macam-macam wakaf poduktif :

\section{Wakaf Uang}

Wakaf uang adalah wakaf yang berasal dari badan maupun perorangan yang berbentuk uang tunai. Uang disini tidak hanya dipandang sebagai alat tukar namun bisa sebagai sesuatu yang memiliki manfaat karena bisa digunakan lebih produktif dengan tujuan memunculkan banyak manfaat bagi umat.

Komisi Fatwa Majelis Ulama Indonesia (MUI) membuat fatwa tentang diperbolehkannya wakaf tunai yang dikeluarkan pada tanggal 11 Mei 2002 yang berisi tentang Wakaf Uang (Cash Wakaf/Waqf al-Nuqud) adalah wakaf yang dilakukan seseorang, kelompok orang, lembaga atau badan hukum dalam bentuk uang tunai. Hokum wakaf uang tunai adalah jawaz (boleh) dan ilai pokok Wakaf Uang harus dijamin kelestariannya, tidak boleh dijual, dihibahkan, dan atau diwariskan.

Aplikasi wakaf uang di Indonesia diatur pada Pasal 28 sampai Pasal 31 ialah wakaf uang harus disetor melalui Lembaga Keluangan Syariah (LKS) yang telah ditetapkan oleh Menteri Agama RI, yaitu BNI Syari'ah, Bank Mu'amalat, Bank Syariah Mandiri, Bank Mega Syariah, Bank DKI Syariah, Bank Bukopin Syariah, Bank Tabungan Negara (BTN) Syariah, dan Bank Jogya Syariah. Wakaf uang harus dibuktikan dengan sertfikat. Menurut Peraturan Badan Wakaf Indonesia (nomor 01 tahun 2009), sertifikat dapat diberikan kepada wakafi yang telah mewakafkan uangnya paling sedikit Rp1.000.000 (satu juta rupiah) dengan menyertakan asal usul uang dan identitas lengkap wakifnya.

\section{Wakaf Saham}

Wakaf saham merupakan termasuk wakaf produktif dan biasanya dilakukan oleh suatu korporasi ataupun perseorangn yang memiliki saham.Wakaf saham adalah perusahaan atau perseorangan yang mewakafkan sekian persen sahamnya melalui lembaga pengelola wakaf yang terpercaya.

Pada April 2019 BEI meluncurkan wakaf saham dengan mekanisme yang sama dengan harta lainnya. Calon wakif nantinya bisa mewakafkan saham melalui mitra yang sudah terdaftar di Anggota Bursa penyedia layanan Sharia Online Trading System (AB-SOTS). Dari 13 AB-SOTS, menurut Hasan, baru ada sekitar enam AB-SOTS yang menjadi mitra. Dalam pengelolaannya, BEI akan bekerja sama dengan Badan Wakaf Indonesia (BWI). Akan ada juga MoU untuk mengikat BEI, BWI dan AB-SOTS untuk memastikan tidak ada kepentingan para wakif yang terabaikan.

Nicky Hogan yang merupakan Direktur Bursa Efek Indonesia (www.ekonomisyariah.org) wakaf saham terbagi menjadi dua model yaitu yang pertama wakaf berasal dari keuntungan investor dan yang kedua adalah wakaf yang menjadikan saham syariah sebagai obyek wakaf. Model yang pertama sumber wakaf berasal dari keuntungan investor saham syariah dan melibatkan AB-SOTS (Anggota Bursa yang mengembangkan Syariah Online Trading Sistem) sebagai institusi yang akan melakukan pemotongan keuntungan.

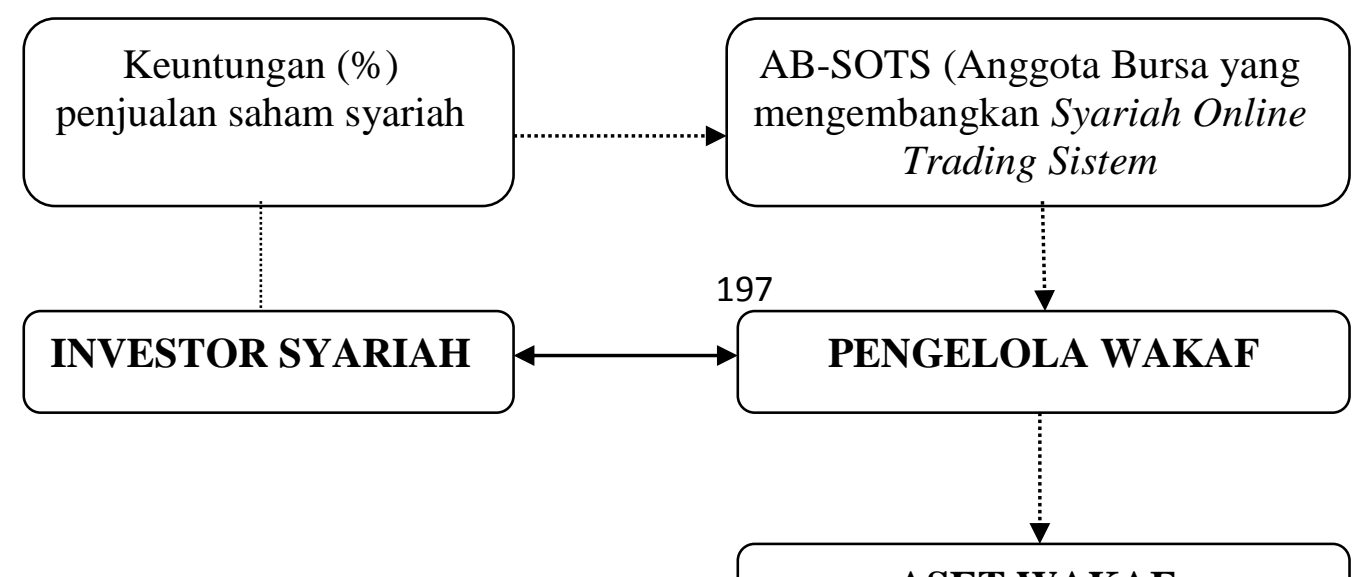


perjanjian

$$
\operatorname{Rp}
$$

\section{Gambar 1. Wakaf Saham Model 1}

Sumber : Hogan, 2016

Model yang kedua merupakan saham syariah yang dibeli oleh investor lalu diserahkan kepada lembaga pengelola investasi yang keuntungan dari saham syariah tersebut akan diserahkan kepada lembaga pengelola wakaf yang akan dikonversikan menjadi asset produktif maupun sosial.

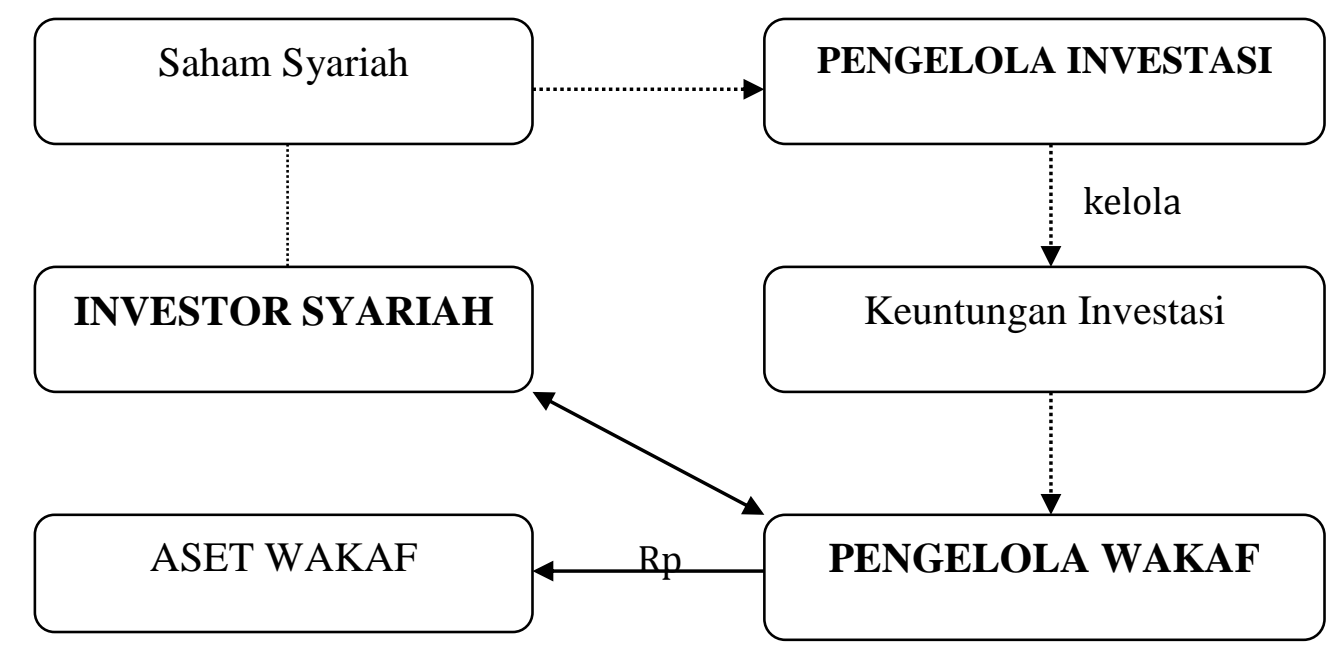

Gambar 2. Wakaf Saham Model 2

Sumber : Hogan, 2016

\section{Wakaf Polis Asuransi Syariah}

Asuransi syariah atau takaful berdasarkan fatwa DSN MUI No: 21/DSN-MUI/X/2001 adalah usaha saling melindungi dan tolong menolong diantara sejumlah orang melalui investasi dalam asset dan atau tabarru' yang memberikan pola pengembalian untuk menghadapi resiko tertentu melalui akad yang sesuai dengan syariah. Seiring dengan berkembangnya asuransi syariah di Indoesia maka ini dapat dilihat sebgai peluang yang besar untuk dijadikan wakaf produktif asalkan seusai dengan aturan syariat. DSN MUI mengeluarkan fatwanya mengenai wakaf polis asuaransi syariah yaitu No: 106/DSN-MUI/X/2016. Dalam fatwa tersebut terdapat 2 hal yang dapat diwakafkan adalah manfaat asuransi dan manfaat investasi. Manfaat asuransi adalah dana yang berasal dari dana tabarru' yang diberikan kepada pihak yang lebih membutuhkan sedangkan manfaat investasi adalah dana yang diserahkan kepada peserta progam asuransi yang berasal dari investasi peserta dan hasil dari investsinya. 
Salah satu contoh wakaf polis syariah adalah dari Prudential. Dengan diterbitkannya Fatwa MUI 106/DSN-MUI/X/2016, sekarang wakaf juga dapat dilakukan dengan manfaat asuransi dan manfaat investasi dari asuransi jiwa syariah. Prudential Indonesia meluncurkan Program Wakaf dari PRUsyariah yang menawarkan pilihan bagi nasabah dan calon nasabah dalam menyalurkan wakaf.

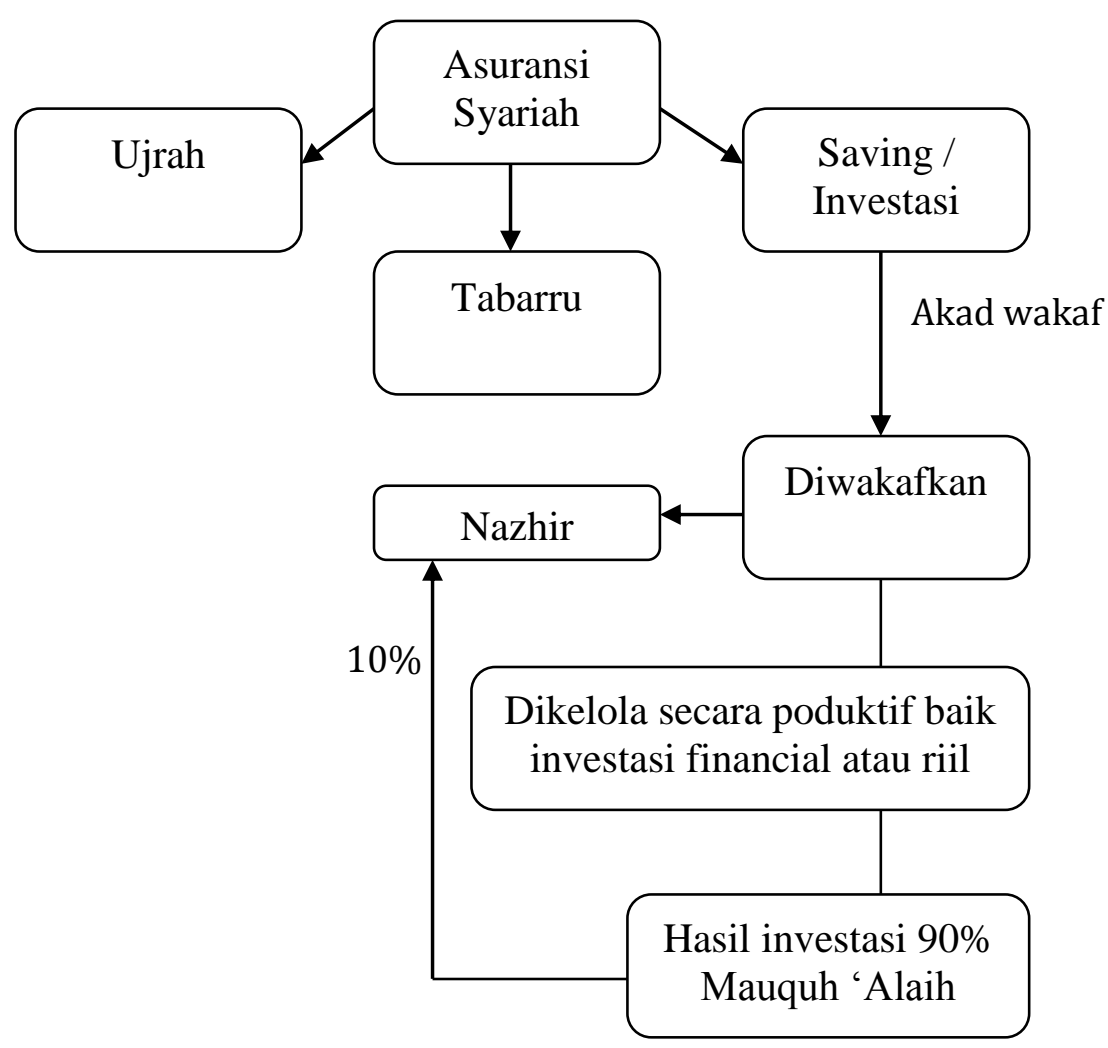

\section{Gambar 3. Mekanisme Pengelolaan Wakaf Polis Asuransi}

Sumber : Sulistiani et al, 2016

\section{Wakaf Perkebunan dan Pertanian}

Wakaf kebun produktif merupakan salah satu program wakaf tunai. Wakaf kebun ini dikelola oleh suatu lembaga sebagai bentuk pendayagunaan kebun yang merupakan program investasi kebun produktif di salah satu lembaga yaitu Rumah Wakaf. Wakaf kebun produktif ini bertujuan agar lahan tidak selalu menjadi bangunan properti melainkan menjadi kebun yang dapat bermanfaat bagi umat. Selain mendapatkan hasil perkebunan yang dapat dimanfaatkan untuk masyarakat, dengan adanya wakaf produktif ini dapat mendayagunakan masyarakat yang memiliki ketrampilan perkebunan namun tidak memiliki lahan ataupun yang belum bekerja dan ingin belajar mengelola perkebunan.

Salah satu lembaga wakaf yaitu Dompet Dhuafa melakuka wakaf produktif di bidang perkebunan sejak tahun 2014 di Subang Jawa Barat. Perkebunan tersebut ditanami buah naga dan buah nanas yang dibina di Desa Corangkong, Kecamatan Cijambe, Kabupaten Subang. Tanag 
wakaf tersebut seluas delapan hektar. Selain dijadikan perkebunan juga dapat dijadikan sebagai pusat wisata dan edukasi pertanian (agrowisata). Banyak warga sekitar yang merasa terbantu dengan adanya perkebunan tersebut. Hasil buah-buahan dapat dijual sehingga menghasilkan uang namun lahan tersebut tetap bisa diolah sehingga bisa menjadi berkelanjutan. (Muhyiddin, 2017)

\section{Wakaf Tanah}

Wakaf tanah adalah menyerahkan sebidang tanah hak milik baik individu maupun kelompok bagi kepentingan sosial. Payung hukum dalam wakaf tanah ini adalah Peraturan Pemerintah no. 28 tahun 1977 tentang Pewakafan Tanah Milik. Masyarakat Indonesia kebanyakan mengenal wakaf adalah wakaf tanah karena pemahaman tentang wakaf produktif yang belum menyeluruh seperti sekarang. Nilai positifnya adalah banyaknya harta wakaf berupa tanah yang ada di Indoneisa.

Berdasarkan data dri Badan Wakaf Indonesia yang bersumber dari Direktorat Pemberdayaan Wakaf Kementerian Agama RI tertanggal Maret 2016 terdapat 435.678 dengan luas 4.359.443.170 m2 tanah wakaf yang ada di Indonesia. Kendala dari wakaf tanah ini adalah ada 148.447 tanah yang belum memiliki sertifikat tanah wakaf sehingga belum dapat dimanfaatkan dengan baik. Berdasarkan penelitian dari Nurhidyani tahun 2017, pengelolaan tanah wakaf yang dilakukan pada Lembaga Amil Zakat Dompet Amal Sejahtera Ibnu Abbas (DASI) Nusa Tenggara Barat adalah pesantren kemandirian, rumah tahfidz dan tanah kemanfaatan. Pesantren kemandirian adalah memanfaatkan rumah dan lahan tanah untuk diajarkan kewirausahaan mandiri selain disekolahkan dan dibina oleh seorangpengasuh dari keluarga duafa. Sementara rumah tahfidz adalah program mencetak tahfidz yang penerimanya merupakan anak yatim sedangkan tanah kemanfaatan adalah progam bercocok tanam dan berkebun yang dilakukan di tanah wakaf dan dikejakan oleh seorang yang ditunjuk oleh DASI yang langsung sebgai penerima manfaat hasilnya.

\section{Wakaf Transpotasi}

Wakaf transportasi adalah wakaf produktif yang dihimpun secara tunai sesuai dengan akad lalu dibelikan alat transportasi untuk kepentingan umum. Besaran dana wakaf ditentukan oleh masing-masing lembaga wakaf, misalnya saja pada lembaga Al Azhar (Salam, 2015) sebesar Rp 25.000. Hasil dari wakaf ini adalah untuk pembelian alat transportasi baik darat, laut maupun udara. Lalu alat transportasi tersebut disewakan dan hasilnya dapat digunakan untuk kepentingan umat.

Wakaf transportasi biasanya adalah dari wakaf tunai yang digunakan untuk membeli alat transportasi. Salah satu lembaga wakaf yang sudah menjalankan adalah Wakaf Al Azhar. Harga perlembar saham wakaf transportasi adalah Rp 25.000,- (Rp 20.000/unit+Rp 5.000 operasional) (www.wakaf alazhar.or.id, 2015). Wakaf transportasi ini dibagi menjadi 4 yaitu transportasi privat contohnya adalah usaha antar-jemput sekolah ataupun karyawan, transportasi semi privat meliputi usaha rental mobil, transportasi semi umum adalah bisnis travel yang dibagi menjadi travel konvensional dan travel point to point, transportasi umum berplat kuning.

\section{Wakaf Air / Sumur}


Utsman bin Affan RA merupakan salah satu sahabat Rosulullah SAW yang dikenal dengan kerdermawanannya. Kisah ini berawal hijrahnya kaum muslim hijrah dari Makkah ke Madinah sehingga kebutuhan air bersih semakin meningkat sementara umat Islam di Madinah hanya mengandalkan sumur yang di miliki oleh seorang Yahudi. Ketika umat Islam akan membeli sumur tersebut lalu pemiliknya menjual dengan harga yang tinggi hingga Rosulullah SAW menawarkan kebun yang luas sebagai gantinya namun tawaran tersebut ditolak. Akhirnya Usman bin Affan menawarkan system sewa dengan mekanisme pemilik dan penyewa akan menggunakan sumur itu secara bergantian setiap harinya namun pemilik merasa rugi hingga akhirnya pemilik menjual sumur seharga 20.000 dirham

Wakaf produktif yang saat ini sedang dikembangkan dan sangat dibutuhkan daerahdaerah di Indonesia dan di dunia pada khususnya. Sumur ini bisa digunakan untuk memenuhi kebutuhan sehari-hari dan juga digunakan sebagai irigasi karena Indonesia merupakan negara agraris yang mata pencaharian penduduknya masih bertani dan berkebun. Beberapa daerah di Indonesia ketika musim kemarau masih sangat membutuhkan air bersih misalnya Indonesia bagian timur. Ada beberapa lembaga pengelola wakaf di Indonesia yang sudah mulai mengembangkan wakaf air. Salah satunya adalah Aksi Cepat Tanggap yang sudah melakukan program wakaf air yang menjadi bagian dari Global Water Program. Global Water Program adalah suatu program pengadaan air bersih untuk meningkatkan kualitas hidup masyarakat yang berada di daerah terpencil, dilanda kekeringan, terjadi bencana dan minim akses. Salah satu keuntungan wakaf sumur adalah selama sumur itu masih mengalirkan air maka pahala bagi wakif masih mengalir.

\section{Kontribusi Wakaf Produktif dalam Perekonomian}

Indonesia merupakan negara yang mayoritas masyarakatnya muslim yang mengalami fenomena kemiskinan yang hampir belum bisa terselesaikan dengan tingkat kemiskinan menurut BPS bulan September taun 2018 mencapai 9,66\% dari jumlah penduduk Indonesia yaitu sebesar 25,67 juta masyarakat termasuk dalam masyarakat miskin. Berbagai solusi yang sudah dilakukan pemerintah seakan belum bisa mengatasi permasalahan kemiskinan yang ada di masyarakat. Salah satu solusi yang ditawarkan oleh penulis adalah menggunakan wakaf produktif yang harus digalakan di Indonesia sehingga bisa mengurangi kemiskinan.

Masalah wakaf merupakan masalah yang sampai saat ini belum dibahas secara intensif dan serius oleh pemerintah, padahal jika lebih fokus untuk dibahas dan menjadi program maka ini dapat membantu pemerintah secara tidak langsung dalam mengurangi kemiskinan. Umat Islam di Indonesia juga kurang familiar atau bahkan belum mengetahui istilah wakaf produktif itu sendiri. Karena banyaknya pemahaman yang berbeda di kalangan umat Islam itu sendiri. Mayoritas masyarakat di Indonesia masih memahami wakaf sebatas benda-benda yang tidak bergerak, seperti tanah, bangunan yang digunakan untuk masjid, pondok pesantren, panti asuhan dan kuburan. Sangat dibutuhkan sosialisasi untuk mengubah paradigma ini dimasyarakat sehingga wakaf dapat lebih dimaksimalkan kegunaannya.

Pemerintah juga sudah menerbitkan undang-undang yang membahas tentang wakaf di Indonesia, yaitu UU No 41 Tahun 2004 tentang wakaf yang kemudian dilengkapi dengan PP No 42 Tahun 2006 tentang pelaksanaannya. Adanya peraturan tersebut diharapkan dapat memaksimalkan potensi wakaf produktif di Indonesia. Data pada 4 Januari 2017 menyatakan bahwa jumlah tanah wakaf yang ada di Indonesia saat ini mencapai $4.359 .443 .170 \mathrm{~m} 2$ yang berada pada 435.768 lokasi. 
Luasnya tanah wakaf di Indonesia ini bersifat produktif, dengan melihat sumber daya alam yang ada di Indonesia sangatlah potensial untuk diolah kembali sehingga menghasilkan produk yang berguna bagi masyarakat dan dapat menyerap tenaga kerja. Islam mengajarkan untuk tidak membiarkan tanah terbengkalai begitu saja, apalagi itu bisa digunakan untuk kepentingan umat Islam. Tantangan bagi semua masyarakat di Indoensia baik pemerintah, masyarakat maupun lembaga wakaf untuk dapat memberdayakan tanah tersebut. Seperti yang telah disebutkan tentang luas tanah wakaf dan pemahaman masyarakat tentang wakaf, karena pemahaman wakaf hanya untuk bidang social saja maka seringkali pemilik tanah wakaf tidak mengijinkan jika tanahnya diolah menjadi wakaf produktif sehingga tanah dibiarkan begitu saja. Barangkali ini menjadi salah satu penyeban banyaknya tanah wakaf yang terbengkalai.

\section{KESIMPULAN}

Wakaf merupakan salah satu ibadah yang menggunakan asas filantropi diamping zakat, infak, shodaqoh. Wakaf menjadi salah satu pilihan alternatif dalam mengatasi permasalahan ekonomi mislnya kemiskinan. Pemerintah sudah menerbitkan beberapa peraturan perundangundangan tentang wakaf yang menjadi angin segar bagi para pengelola wakaf agar dapat mengelola dengan maksimal dana wakaf yang ada.

Pemahaman tentang wakaf di masyarakat juga menjadi salah satu permasalahan karena masyarakat hanya mengenal wakaf konsumtif saja sementara itu wakaf produktif sebenarnya sangat berpotensial bagi pengentasan kemiskinan dan berbagai masalah perekonomian. Dengan memaksimalkan wakaf produktif diharapkan dapat bermanfaat bagi masyarakat yang membutuhkan. Wakaf konsumtif yangs sering kita dengar misalanya saja adalah membangun sebuah fasilitas umum yang membantu masyarakat misalnya saja masjid, kuburan, mushola ataupun sekolah. Namun kelemahnnya adalah fasilitas umum tersebut membutuhkan biaya operasional yang tidak sedikit. Solusi dari permasalahan tersebut adalah menggunakna wakaf produktif. Munzir Qahaf dalam Mubarok (2013) mendefinisikan wakaf produktif yaitu harta wakaf yang digunakan untuk kepentingan produksi dan hasilnya dimanfaatkan untuk tujuan wakaf tersebut, misalnya saja dalam bidang pertanian, peternakan, perkebunan dan lain sebagainya. Macam wakaf produktif di Indonesia terdiri dari Wakaf Uang, Wakaf Saham, Wakaf Polis Asuransi Syariah, Wakaf Perkebunan dan Pertanian, Wakaf Tanah, Wakaf Transpotasi, dan Wakaf Air / Sumur.

Wakaf Produktif menjaga pokok wakaf agar tetap utuh dan mendapatkan keuntungan. Keuntungan wakaf tersebut dapat digunakan dan berguna bagi umat tanpa menghilangkan pokok wakaf tersebut sehingga pokok wakaf tersebut dapat dikelola secara berkelanjutan sehingga dapat menghasilkan keuntungan yang lebih bermanfaat bagi orang banyak.

\section{DAFTAR PUSTAKA}

Hazami, B. (2016). Peran dan Aplikasi Wakaf dalam Mewujudkan Kesejahteraan Umat di Indonesia . Universitas Airlangga Surabaya .

Intan, N. (2017). BWI Targetkan Dana Penghimpun Wakaf Rp800. Dipetik Juli 3, 2019, dari https://www.republika.co.id/berita/dunia-islam/wakaf/17/12/14/p0ylvz335-bwi-targetakadana-penghimpun-wakaf-rp-800

Manajemen Wakaf Transportasi. (2015, April 3). Dipetik Agustus 4, 2019, dari http://wakafalazhar.or.id/produk/6-Wakaf+Transportasi/ 
Masyrafina, I. (2017, Maret 1). Pemerintah Harus Dorong Pemanfaatan Wakaf Tunai. Dipetik Februari 9, 2018, dari http://www.ekonomisyariah.org/5620/mengenal-wakaf-saham/

Mubarok. (2013). Model Pengembangan Wakaf Produktif ( Studi tentang Pengelolaan Wakaf pada Yayasan Muslimin kota Pekalongan). . Jurnal Hukum Islma Volume 11.

Mubarok, J. (2008). Wakaf Produktif. Bandung: Simbiosa Rektama Media.

Muhyiddin. (2017). Wakaf Produktif Pertanian Sejahterakan Petani Subang. Dipetik Agustus 4, 2018, dari https://khazanah.republika.co.id/berita/duniaislam/wakaf/17/10/26/oyfmmj396-wakafproduktif-pertanian-sejahterakan-petani-subang.

Munir, Z. A. (2013). Revitalisasi Manajemen Wakaf Sebagai Penggerak Ekonomi Masyarakat. Journal de Jure 5 (2).https://doi.org/10.18860/jfsh.v5i2.3007 .

Nurhidayani, M. Y. (2017). Pengelolaan dan Pemanfaatan Tanah Wakaf dan Bangunan. Maqdis : Jurnal Kajian Ekonomi Islam - Volume 2, Nomor 2, Juli-Desember 2017.

Panduan Pengelolaan Wakaf Tunai. (2013). Diambil kembali dari Kementrian Agama Republik Indonesia: Direktorat Jenderal Bimbingan Masyarakat Islam Direktorat Pemberdayaan Wakaf

Persentase Penduduk Miskin Pada September 2018 Sebesar 9,66 Persen. (2018). Dipetik Januari 24, 2019, dari https://www.bps.go.id/pressrelease/2019/01/15/1549/persentase-penduduk-miskin-padaseptember-2018-sebesar-9-66-persen.html

Prayogo, A. (2018, November 1). Jumlah Tanah Wakaf di Indonesia Mencapai 4.359.443.170 Meter Persegi. Dipetik Juli 4, 2018, dari https://wartakota.tribunnews.com/2018/11/01/jumlah-tanah-wakaf-diindonesia-mencapai-4359443170-meter-persegi.

Primadhyta, S. (2017). BWI Sebut Baru 62\% Tanah Wakaf Tersertifikasi. Dipetik Januari 4, 2019, dari https://www.cnnindonesia.com/ekonomi/20171108202541-92-254431/bwi-sebut-baru-62persen-tanah-wakaf-tersertifikasi

Sabiq, S. (2008). Fikih Sunnah. Penerbit Pena.

Salam, A. A. (2015). Manajemen Wakaf Transportasi Pada Lembaga Wakaf Al-Azhar. Skripsi : Universitas Islam Negeri Syarif Hidayatullah .

Setiaji, A. T. (2017). Badan Wakaf Indonesia (BWI): Potensi Wakaf di Indonesia Mencapai 180 Triliyun. Dipetik Januari 18, 2018, dari http://mysharing.co/badan-wakaf-indonesia-bwi-potensi-wakaf-diindonesia-mencapai-180-triliyun/

Sulistiani, S. L. (2016). Wakaf Polis Asuransi Perspektif Ekonomi Islam untuk Pemberdayaan Umat. Prosiding Seminar Nasional Penelitian dan PKM Sosial, Ekonomi dan Humaniora Volum 6 No 1 .

Syarat-Syarat Wakaf. (2018, Februari 17). Dipetik Juli 3, 2019, dari https://zakat.or.id/syarat-syaratwakaf/

Tuasikal, M. A. (2016, November 2). Hadits Wakaf (02) : Aturan Penting Wakaf. Dipetik Januari 25, 2019, dari https://rumaysho.com/14693-hadits-wakaf-02-aturan-penting-wakaf.html

UU No. 41 Tahun 2004 tentang Wakaf. (2019). Dipetik Januari24 2019, dari https://kemenag.go.id/file/dokumen/UU4104.pdf

Wasilah, S. N. (2015). Akuntansi Syariah di Indonesia. Jakarta: Salemba 4. Edisi 4. 